\title{
Article \\ Exploring Two Streptomyces Species to Control Rhizoctonia solani in Tomato
}

\author{
Marzieh Ebrahimi-Zarandi ${ }^{1}$ (D), Gholam Hosein Shahidi Bonjar 1,2,*(D), Roohallah Saberi Riseh ${ }^{3}$, \\ Mohamed El-Shetehy ${ }^{4,5}$ (D) Ismail Saadoun ${ }^{6}$ and Essaid Ait Barka ${ }^{7, *(D)}$
}

1 Department of Plant Protection, Faculty of Agriculture, Shahid Bahonar University of Kerman, Kerman 7618411764, Iran; ebrahimimarzieh@gmail.com

2 Medical Mycology and Bacteriology Research Center, Kerman University of Medical Sciences, Kerman 7616913555, Iran

3 Department of Plant Protection, Faculty of Agriculture, Vali-e-Asr University of Rafsanjan, Rafsanjan 7718897111, Iran; r.saberi@vru.ac.ir

4 Department of Biology, Faculty of Science and Medicine, University of Fribourg, CH-1700 Fribourg, Switzerland; m.shetehy@uky.edu

5 Department of Botany, Faculty of Science, Tanta University, Tanta 31527, Egypt

6 Department of Applied Biology, College of Sciences, University of Sharjah, Sharjah P.O. Box 2727, United Arab Emirates; isaadoun@sharjah.ac.ae

7 Induced Resistance and Plant BioProtection Research Unit, UFR Sciences, UPRES EA 4707-USC INRAE1488, University of Reims Champagne-Ardenne, 51687 Reims, France

* Correspondence: shahidi@uk.ac.ir (G.H.S.B.); ea.barka@univ-reims.fr (E.A.B.)

Citation: Ebrahimi-Zarandi, M.; Bonjar, G.H.S.; Riseh, R.S.; El-Shetehy, M.; Saadoun, I.; Barka, E.A. Exploring Two Streptomyces Species to Control Rhizoctonia solani in Tomato. Agronomy 2021, 11, 1384. https:// doi.org/10.3390/agronomy11071384

Academic Editor: Ana Segura

Received: 5 June 2021

Accepted: 6 July 2021

Published: 8 July 2021

Publisher's Note: MDPI stays neutral with regard to jurisdictional claims in published maps and institutional affiliations.

Copyright: (c) 2021 by the authors. Licensee MDPI, Basel, Switzerland. This article is an open access article distributed under the terms and conditions of the Creative Commons Attribution (CC BY) license (https:/ / creativecommons.org/licenses/by/ $4.0 /)$.

\begin{abstract}
Streptomyces species are effective biocontrol agents toward many plant pathogens. These microorganisms are well known for producing secondary metabolites, promoting plant growth and inducing plant defense mechanisms. In this study, the ability of tomato root-colonizing Streptomyces strains to trigger the resistance against Rhizoctonia solani (J.G. Kühn) AG4 was investigated. For this goal, we evaluated the pattern of $L O X B$ and PAL1 genes expression changes upon pathogen inoculation in primed tomato plants. The results revealed that Streptomyces globisporous (Krasil'nikov) strain F8 and S. praecox (Millard and Burr) strain R7 were able to enhance the expression of lipoxygenase and phenylalanine ammonia lyase in tomato plants. This finding suggests that Streptomyces strains F8 and R7 may trigger jasmonic acid and phenyl propanoid signaling pathways in plants, therefore, resulting an induced defense status in tomatoes against $R$. solani. Biochemical characterization of these Streptomyces strains showed that they were strong producers of siderophores. S. praecox strain R7 produced siderophores of hyderoxamate and catechol types and S. globisporous strain F8 produced a phenolic siderophore. Moreover, they also produced protease while only the S. praecox strain R7 was able to produce amylase. Taken together, these results indicate that S. globisporous strain F8 and S. praecox strain R7 promote plant growth and reduces disease and hence are suitable for future in depth and field studies with the aim to attain appropriate biocontrol agents to protect tomatoes against $R$. solani.
\end{abstract}

Keywords: defense response; gene expression; Rhizoctonia solani AG4; siderophores; Streptomyces

\section{Introduction}

Investigation on the relationship between microbiota and their host plants is crucial for innovative sustainable agriculture. In addition to managing abiotic and biotic stresses in plants, Plant Growth Promoting Rhizobacteria (PGPR) affect the plants fitness and growth in two different manners, which are directly or indirectly. While PGPR are able to trigger plant growth by mobilizing nutrients in soils or producing numerous growth regulators, they protect plants from plant pathogens either by controlling invaders or by triggering plant defense mechanisms. During last decades, "induced resistance" to diseases or plant "immunization" has received interesting attention. Colonization of plant roots 
by PGPR can induce a systemic resistance in plants [1]. Primed plants respond faster and stronger defense responses to future stresses, which is a process named priming [2-5]. Priming can be long lasting and several reports indicated that descendants of primed plants expressed next-generation systemic acquired resistance [6-8]. It is a cost effective defense mechanism [9] and the resulting induced resistance can protect plants against a broad spectrum of attackers [10].

The phylum Actinobacteria is considered as one of the largest taxonomic unit among the major lineages currently recognized within the bacteria domain [11]. Actinomycetes include a large portion of rhizosphere microbial community and are capable of colonizing the plants root [12]. Furthermore, they are of great interest in the field of biotechnology, as they produce of a plethora of bioactive secondary metabolites with extensive medical, industrial and agricultural applications [11,13-18]. In addition to their direct toxic effects on other microbes, several secondary metabolites produced by actinobacteria have been suggested to trigger plant defenses, improving the plant's protection against pathogens [12].

Streptomyces spp. were able to protect tomatoes against $R$. solani and enhance the accumulation of phenolic compounds in plants [19]. Similarly, Singh et al. [20] through biochemical characterization revealed an enhancement in defense related enzymes levels in tomatoes treated with actinomycetes isolated from vermicompost, which were then challenged with R. solani. Kurth et al. [21] noticed that the Streptomyces sp. strain AcH 505 elicited systemic defense responses upon a Microsphaera alphitoides challenge. Induction of systemic resistance in different tomato cultivars against Botrytis cinerea by Micromonospora strains isolated from legume root nodules has been reported by Martinez-Hidalgo et al. [22]. The ability of proteolytic actinomycetes to induce resistance against the Sclerospora graminicola causal agent of downy mildew in millet was demonstrated by Jogaiah et al. [23]. Singh and Gaur [24] reported that the chickpea plants treated with endophytic Streptomyces spp. under Sclerotium rolfsii stress exhibited higher levels of defense enzymes and accumulated phenols. Abbasi and her colleagues in 2019 noticed that two Streptomyces strains were able to induce resistance in tomatoes against Fusarium oxysporum f.sp. lycopersici [25]. Rhizospheric Streptomyces spp. and endophytes involving Pseudomonas putida and Metarhizium anisopliae induced defense responses in rice against Xanthomonas oryzae pv. oryzae [26]. Although there are a number of reports on the implication of actinomycetes as inducers of plant defense responses, these microorganisms are still less explored for the development of host resistance in comparison with other plant growth promoting rhizobacteria.

Rhizoctonia solani Kühn (teleomorph: Tanatephorus cucumeris) is one of the most destructive pathogens in many plants [27]. Tomato crown and root rot caused by R. solani AG4 was found in various tomato production areas in Iran. The control of this pathogen is difficult because of its wide host range, long-term survival in soil and high population variability [28]. Previously, this pathogen was controlled by soil fumigation with methyl bromide, the application of which has been banned for about two decades [29]. The use of other fungicides to control $R$. solani under field conditions is not very effective and has environmental consequences. In order to be in pace with the aims of sustainable environment, it is necessary to find an effective and safe method to control this pathogen. Biological control of $R$. solani in tomatoes has been evaluated with different antagonistic agents in several studies. Goudjal et al. [30] reported that tomato seed treatment with endophytic actinomycetes reduced the severity of $R$. solani damping-off and promoted plant growth The efficacy of Streptomyces spp. to protect tomatoes against $R$. solani and to enhance yield was demonstrated by Singh et al. [20]. In addition to Streptomyces spp., some other microorganisms have proven to act as antagonisms against this phytopathogen. The positive effects of Burkholderia cepacia T1A-2B and Pseudomonas sp. T4B-2A on control of R. solani in the field conditions are indicated by De Curtis et al. [31]. Similar results were reported with Glomus mosseae BEG12 and P. fluorescens A6RI to suppress R. solani in tomatoes [32]. Trichoderma harzianum mutants were effective to control $R$. solani under greenhouse and field conditions [33]. Manganiello et al. [34] also revealed that T. harzianum and its secondary metabolite, harzianic acid, were able to protect tomato plants against $R$. solani by inducing 
the plant defense responses. Interestingly, combination of four microorganisms including Pythium oligandrum, Bacillus subtilis, B. thuringiensis and Enterobacter cloacae suppressed tomato Rhizoctonia root rot [35].

The present study aimed to (i) evaluate inhibitory activity of actinomycete isolates for the control of R. solani AG4, (ii) to evaluate in vivo ability of the isolates to colonize the tomato roots and induction of resistance against the pathogen and (iii) to identify and characterize the selected actinomycetes isolates.

\section{Materials and Methods}

\subsection{Culture Media and Preparation of Pathogen}

Pure culture of R. solani AG4 was obtained from Mycology Collection, Ferdowsi University of Mashhad, Iran. The fungus was cultured on potato dextrose agar (PDA, Difco-39 $\mathrm{g}_{\text {PDA L }}{ }^{-1}$ of distilled $\mathrm{H}_{2} \mathrm{O}, \mathrm{pH}$ 7.2) and kept refrigerated until use. Casein glycerol agar (CGA) was prepared from basic ingredients as described by Küster and Williams [36] and used as actinomycetes culture.

\subsection{Sample Collection and Isolation of Actinomycetes}

Soil samples of rhizosphere were collected from tomato fields in different localities of the Kerman province, Iran, with global positioning system (GPS) of $(30.2192663,57.0290540)$ and $(28.4656225,57.8501318)$. Soil samples $(1 \mathrm{~g})$ were serially diluted at 1:10 using sterile distilled water. Inocula consisted of adding aliquots of $10^{-3}-10^{-6}$ soil dilutions to autoclaved CGA $\left(1.25 \mathrm{~mL}^{-1} \mathrm{CGA}\right)$ at $50^{\circ} \mathrm{C}$ before pouring the plates and solidification. Three replicates were considered for each dilution. Plates were incubated at $28{ }^{\circ} \mathrm{C}$. From the 7th day forward, colonies of actinomycetes were isolated as pure culture on CGA slants and incubated at $28^{\circ} \mathrm{C}$ for one week and then stored at $4{ }^{\circ} \mathrm{C}$ before use [37].

\subsection{In Vitro Bioassays}

To evaluate the antifungal activity of actinomycetes, two sets of isolates were used in the agar disk bioassay method against the pathogen. One set included those isolated from tomato rhizosphere and another set included some isolates from our laboratory collection (Laboratory of Biocontrol of Plant Diseases in Shahid Bahonar University of Kerman, Kerman, Iran). Antifungal activity around the actinomycetes agar disks was evaluated and the ratings performed were as used by Lee and Hwang [38] and El-Tarabily et al. [39].

\subsection{Siderophore Production}

The ability of actinobacterial isolates to produce siderophore was tested by the universal chrome azurol S (CAS) agar assay [40]. In brief, positive producers develop yellow-orange zone around their colonies in CAS agar, which indicate the production of siderophores. The isolates were rated arbitrary into weak $(+)$, moderate $(++)$ and strong $(+++)$ producers. Quantitative estimation of siderophore was performed with liquid CAS assay. The siderophore production during the actinomycetes growth in modified International Streptomyces Project 4 (ISP4) was assessed in liquid CAS medium [40]. Uninoculated ISP4 broth was used as negative control. Quantitative estimation of siderophore was performed by taking of supernatant of actinobacterial cultures grown in ISP4 broth medium [41]. The bacterial cultures were centrifuged at 10,000 rpm for $10 \mathrm{~min}$ and then supernatant $(0.5 \mathrm{~mL})$ of each bacterial culture was mixed with $0.5 \mathrm{mLCAS}$ reagent. After $20 \mathrm{~min}$, the optical density (OD) was measured at $630 \mathrm{~nm}$ by spectrophotometer (Thermo Scientific, USA). Siderophore produced by actinomycetes isolates was calculated in percent siderophore unit (psu) according to the following formula [42].

$$
\text { Siderophore production }(\mathrm{psu})=[(\mathrm{Ar}-\mathrm{As}) \div \mathrm{Ar}] \times 100
$$

Ar: Absorbance of reference (CAS solution and un-inoculated broth).

As: Absorbance of sample (CAS solution and cell free supernatant of sample). 


\subsubsection{Detection of Catechol and Hydroxamate Type Siderophore Solvent Extraction of Siderophore}

Submerged ISP4 actinobacterial cultures of the most potent siderophore producers (R7 and F8) were centrifuged at 10,000 rpm for $10 \mathrm{~min}$ and a supernatant was used to detect siderophore. For catechol siderophores, $10 \mathrm{~mL}$ of supernatant was adjusted to $\mathrm{pH} 2-3$ by the drop wise addition of $0.5 \mathrm{M} \mathrm{HCl}$. Then, siderophore was extracted with 1:5 volume of ethyl acetate and repeated three times to ensure the maximum recovery of siderophore. Ethyl acetate was evaporated by rotary evaporator at $50{ }^{\circ} \mathrm{C}$ and extracted siderophore was suspended in $300 \mu \mathrm{L}$ of methanol [43]. For hydroxamate siderophores, $\mathrm{NaCl}$ was added to $10 \mathrm{~mL}$ of supernatant to a concentration of $300 \mathrm{~g} / \mathrm{L}$ and mixed thoroughly. Then, siderophore was extracted with a 1:5 volume of benzyl alcohol and three volumes of diethyl ether and driven into a 1:20 volume of sterile distilled water. Diethyl ether was removed by evaporation at a rotary evaporator at $50{ }^{\circ} \mathrm{C}$ and extracted siderophore was suspended in methanol [43]. Similarly, these two methods were conducted for culture medium without the use of bacteria as control samples.

\section{Thin Layer Chromatography (TLC)}

The presence of siderophores was confirmed by using TLC. Extracted siderophores that were described before were diluted in methanol, $5 \mu \mathrm{L}$ of this solution was spotted on silica gel plates $(8 \mathrm{~cm} \times 10 \mathrm{~cm})$ and then the spots were allowed to dry.

To detect the hydroxamate siderophore, the plates were developed using butanol: acetic acid: water (12:3:5, $v / v / v)$ solvent system until the solvent front reached approximately the top of the plate. Then, plates were dried and sprayed with $0.1 \mathrm{M} \mathrm{FeCl}_{3}$ in $0.1 \mathrm{~N}$ $\mathrm{HCl}$ [44]. As a positive standard for mobility, 3,4 dihydroxybenzoic acid was used [45]. The same procedure was applied to detect the catechol siderophore with the difference that ethyl acetate: methanol $(9: 1, v / v)$ was used as solvent.

$\mathrm{FeCl}_{3}$ reagent was used to detect both hydroxamate and catechol siderophores. The presence of hydroxamate siderophore was indicated in red color and phenolic compounds such as catechol indicated as blue or greenish. Moreover, Gibbs reagent (2,6dichlorobenzoquinone- 4 chloroimine) was used to detect phenolic compounds and was indicated as brown color.

\subsection{Biochemical Characterization of Selected Actinomycetes Isolates}

In addition to siderophore production, other biochemical characteristics of the selected R7 and F8 actinobacterial isolates were determined in this study, namely protease [46], chitinase [47], amylase [48], volatile compounds production [49], osmotic pressure tolerance [50] and HCN production [51].

\subsection{Molecular Identification of Actinobacteria}

Genomic DNA of the two selected actinobacterial isolates was extracted according to the method described by Atashpaz et al. [52]. The PCR amplification of the 16S rDNA gene was conducted using the universal primers $27 f\left(5^{\prime}\right.$-AGAGTTTGATCCTGGCTCAG-3') and 1492r $\left(5^{\prime}\right.$-CGGTTACCTTGTTACGACTT-3') [53]. PCR was performed by means of a Thermal cycler (Biometra ${ }^{\circledR}$, Analytik Jena, Germany) with the following program: $94{ }^{\circ} \mathrm{C}$ for $3 \mathrm{~min}$ for 1 cycle; $94{ }^{\circ} \mathrm{C}$ for $1 \mathrm{~min}, 55^{\circ} \mathrm{C}$ for $45 \mathrm{~s}$ and $72{ }^{\circ} \mathrm{C}$ for $1.5 \mathrm{~min}$ for $15 \mathrm{cycles}$; and $72{ }^{\circ} \mathrm{C}$ for $10 \mathrm{~min}$ for 1 cycle. PCR products $(\sim 1500 \mathrm{bp})$ were purified by PCR purification kit (NucleoSpin ${ }^{\circledR}$ Gel and PCR Clean-up, USA). The PCR amplified sequences of both R7 and F8 actinobacterial isolates were submitted to GenBank with the accession numbers of MW857093 and MW857095, respectively. The sequences were searched for similarity to other sequences available in the NCBI database using the basic local alignment search tool (BLAST) algorithm (https:/ / blast.ncbi.nlm.nih.gov / Blast.cgi; accessed on 27 June 2020). The alignment of the sequences was performed with corresponding sequences of the available Streptomyces species deposited in GenBank using the Clustal W and the phylogenetic tree was inferred using the neighbor-joining method in the MEGA 6.06 software. 


\subsection{Root Colonization Test}

To evaluate the ability of actinomycetes isolates to colonize tomato roots; tomato seeds cv. Superchief (https://poponik.com/product/super-chef-tomato/; accessed on 27 February 2019) were surface sterilized by 1\% sodium hypochlorite for $1 \mathrm{~min}$ and rinsed in sterile distilled water twice. Then, the seeds were immerged in a suspension of actinomycetes spores $\left(10^{8}\right.$ spores $\left.\mathrm{mL}^{-1}\right)$ and shaken for $20 \mathrm{~min}$. Actinomycetes-coated seeds were placed on filter paper on water-agar medium and incubated at $25^{\circ} \mathrm{C}$. When the seeds had germinated and the primary roots had elongated to about $5 \mathrm{~cm}$, elongation zones of approximately 3-4 $\mathrm{mm}$ were cut and transferred on CGA medium. The test plates were incubated at $29^{\circ} \mathrm{C}$ for 3-5 days and examined daily to monitor the growth of actinomycetes from the excised root elongation zones.

\subsection{Greenhouse Experiments}

Tomato (Solanum lycopersicum) cv. Superchief susceptible to R. solani AG4 was used in greenhouse experiments. Seeds were surface sterilized by $1 \%$ sodium hypochlorite for $1 \mathrm{~min}$ and rinsed three times in sterile distilled water. Seeds were placed on sterile standard horticultural peat until the first true leaf appeared and then transplanted to plastic pots $(15 \mathrm{~cm} \times 20 \mathrm{~cm})$ with the same mixture as above. The plants were then divided into four groups and four pots in each and treated in the following groups: (i) pathogen alone, (ii) actinomycetes isolate, (iii) actinomycetes isolate plus pathogen and (iv) control (untreated plants). Plants were grown in a greenhouse at $30 \pm 2{ }^{\circ} \mathrm{C}$ with a photoperiod of $16 / 8 \mathrm{~h}$ and $60 \%$ humidity. The plants were inoculated immediately after transplantation with four actinomycetes isolates (R7, F8, BH4-1 and BH4-3). The last two isolates were identified as two strains of Streptomyces misionensis (Cercos et al.) by Torabi et al. [54] and were used for a biocontrol test in greenhouse with those that displayed an inhibition zone against pathogens in Petri dishes (BH4-1 and BH4-3 isolates) and those that did not (R7 and F8 isolates). Inoculation of tomato plants was performed with $3 \mathrm{~mL}$ of bacterial suspensions $\left(10^{8}\right.$ spores $\left.\mathrm{mL}^{-1}\right)$ of each actinomycetes isolate grown on solid medium. The bacterial suspensions were strewn in the soil near the root of the tomato seedling. After three weeks, plants were inoculated with the $R$. solani AG4 using colonized wheat grains. To prepare the pathogen inoculum, $500 \mathrm{~mL}$ flasks containing $100 \mathrm{~g}$ sterile wheat grains were inoculated with 10 plugs containing the pathogen cultured on PDA for 5 days. Then, the flasks were incubated at $28{ }^{\circ} \mathrm{C}$ for three weeks and shaken at least twice to aid colonization $[55,56]$. Colonized wheat grains were filled $1 \mathrm{~cm}$ above the soil surface, which contained $10 \mathrm{~g}$ of wheat grain inocula per pot. The inoculated plants were grown in greenhouse conditions as described above. After one month, the tomato seedlings were carefully removed from the soil and washed with tap water. Disease severity was rated using a 5 class scale as described by Fery and Dukes [57] and then the seedlings were incubated for $48 \mathrm{~h}$ at $60{ }^{\circ} \mathrm{C}$ to measure the dry weights. According to assessment, plant growth parameters and disease reduction resulted in the biocontrol experiment and two actinomycetes isolates were selected for the next greenhouse experiment to evaluate the ability of these isolates to induce resistance against the pathogen in plants. The procedure of this experiment was similar to the first one but the plants were inoculated with the pathogen two weeks after inoculation with the actinomycetes isolates.

\subsection{RNA Extraction and qPCR Analysis of the Defense Related Genes}

To evaluate the expression of defense related genes, the tomato seedlings were harvested at different time points: $0,4,5$ and 6 days after pathogen inoculation (dpi); 0 dpi implies the first hours of pathogen infection and 4,5 and $6 \mathrm{dpi}$ are indicative of the days of post inoculations. Leaves and roots samples were flash frozen in liquid nitrogen and stored at $-70{ }^{\circ} \mathrm{C}$ until required. Tissues were ground with ball mill (Retsch $\left.{ }^{\circledR}, \mathrm{MM} 400\right)$ using glass beads and total RNA was extracted from tomato leaves and roots by a Trizol reagent (Sigma Chemicals, Saint Louis, MI, USA). The concentration of extracted RNA was measured by NanoDrop ${ }^{\circledR}$ ND-1000 UV-Vis Spectrophotometer (Thermo Scientific, Waltham, MA, USA). 
cDNA was synthesized from $1 \mu \mathrm{g}$ of DNase treated total RNA using Omniscript RT kit (Qiagen, Hilden, Germany) according to the manufacturer's instructions. Quantitative real time polymerase chain reaction ( $\mathrm{PPCR}$ ) experiments were carried out in a final volume $15 \mu \mathrm{L}$ containing $5 \mu \mathrm{L}$ of template cDNA, $1 \mu \mathrm{L}(1 \mathrm{pmol})$ primers mix and $7.5 \mu \mathrm{L}$ SensiFast SYBR $^{\circledR}$ Green mix (LABGENE Scientific, Châtel-St-Denis, Switzerland). Quantitative real time PCR was performed with two biological replicates of each cDNA sample in the MIC qPCR cycler (Bio Molecular Systems, Upper Coomera, Queensland, Australia). The PCR program was as follows: $95{ }^{\circ} \mathrm{C}$ for $15 \mathrm{~s}, 60{ }^{\circ} \mathrm{C}$ for $15 \mathrm{~s}$ and $72{ }^{\circ} \mathrm{C}$ for $30 \mathrm{~s}$ (45 cycles). The reference gene $E F-1 \alpha$ was used to normalize the experimental genes. QPCR primers for the PAL1 and LOXB genes were prepared by Microsynth AG (Switzerland). The primer sequences used in this study are presented in Table 1. Relative expression of genes was calculated according to Livak and Schmittgen [58].

Table 1. The list of the primers used in qPCR experiment.

\begin{tabular}{ccc}
\hline Gene Name & \multicolumn{1}{c}{ Primer Sequences } & Reference \\
\hline \multirow{2}{*}{ PAL1 } & F-TCGTTATGCTCTCCGAACATCT & Chandrasekaran and Chun [59] \\
& R-ATTCACTGAGTTAATCTCCCTCTC & Song et al. [60] \\
\hline \multirow{2}{*}{ LOXB } & $\begin{array}{c}\text { F-ATCTCCCAAGTGAAACACCACA } \\
\text { R-TCATAAACCCTGTCCCATTCTTC }\end{array}$ & Rotenberg et al. [61] \\
\hline \multirow{2}{*}{$E F-1 \alpha$} & F- GATTGGTGGTATTGGAACTGTC & \\
& R-GCTTCGTGGTGCATCTCA & \\
\hline
\end{tabular}

\subsection{Statistical Analysis}

The statistical analysis was performed using SPSS software version 22.0 (SPSS Inc., Chicago, IL, USA) and data were processed by one-way analysis of variance (ANOVA). The significant differences of the results were determined using LSD test at $p \leq 0.05$.

\section{Results}

\subsection{In Vitro Antagonistic Bioassays}

A total of 38 pure actinomycetes isolates were collected from the screening study and then evaluated according to their antagonistic effect toward $R$. solani AG4. From the tested isolates, 10 were active in dual culture method and two indicated strong antifungal activity (Figure 1a). None of actinomycetes isolates collected from tomato rhizosphere showed strong antifungal activity against the pathogen (Figure $1 \mathrm{~b}$ ).

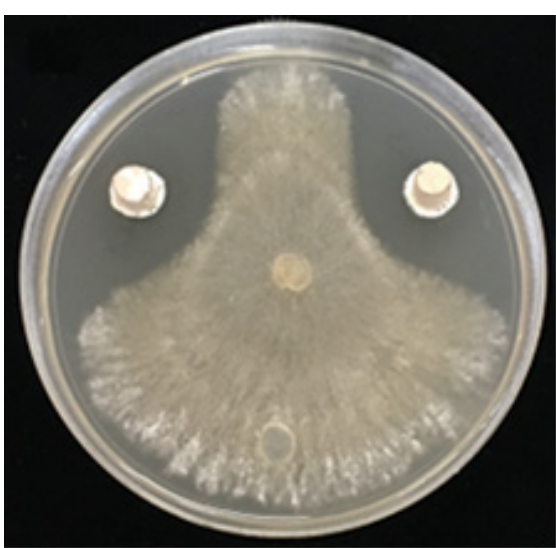

(a)

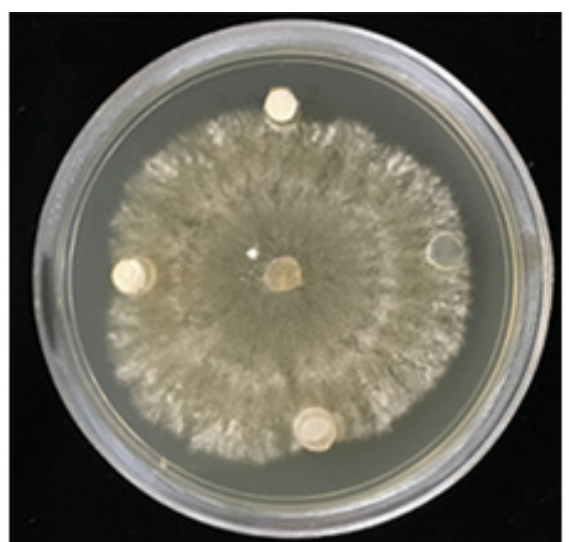

(b)

Figure 1. Bioassay results of actinomycetes isolates against Rhizoctonia solani AG4. (a) Clockwise from top right: actinomycetes isolate BH4-1, blank agar disk (control), actinomycetes isolate BH4-3; center: R. solani AG4; (b) Clockwise from top: actinomycetes isolate F8; blank agar disk (control); actinomycetes isolates 115 and R7; center: R. solani AG4. 


\subsection{Siderophore Production}

Formation of an orange halo around actinomycetes colonies in the CAS agar medium was observed for both R7 and F8 isolates, which are indicative of siderophore production by these two isolates. Results indicated that both R7 and F8 isolates were rated as strong siderophore producers as they showed fast color changes ( $<15 \mathrm{~min}$ ) in the liquid CAS assay. Concentration of siderophore produced by R7 and F8 isolates was measured 71.41 and $45.73 \mathrm{psu}$, respectively (Figure 2). TLC analysis for each isolate showed that R7 isolate produced a siderophore of hyderoxamate type and another one of catechol type with lower concentration. F8 isolate produced a phenolic siderophore (Figure 3).

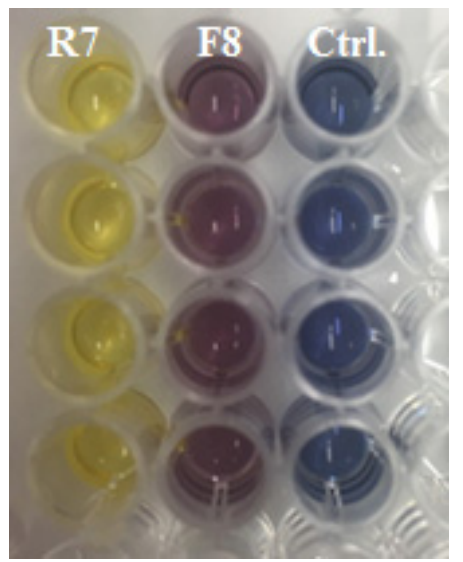

Figure 2. Estimation of siderophore production by two actinomycetes isolates in liquid CAS medium. Siderophore production is positive in both isolates R7 (color changed from blue to yellow) and F8 (color changed from blue to pink) compared to the control (blue, no color change).

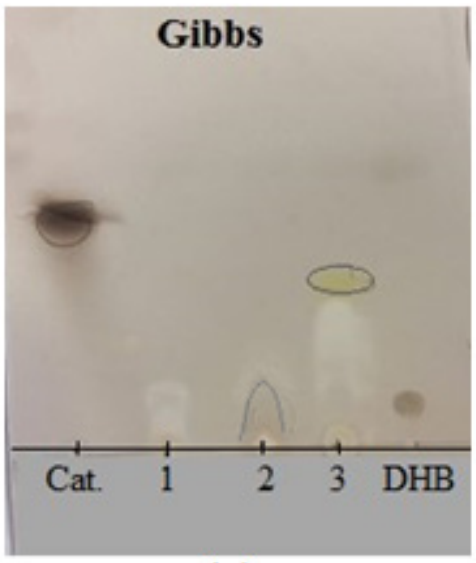

(a)

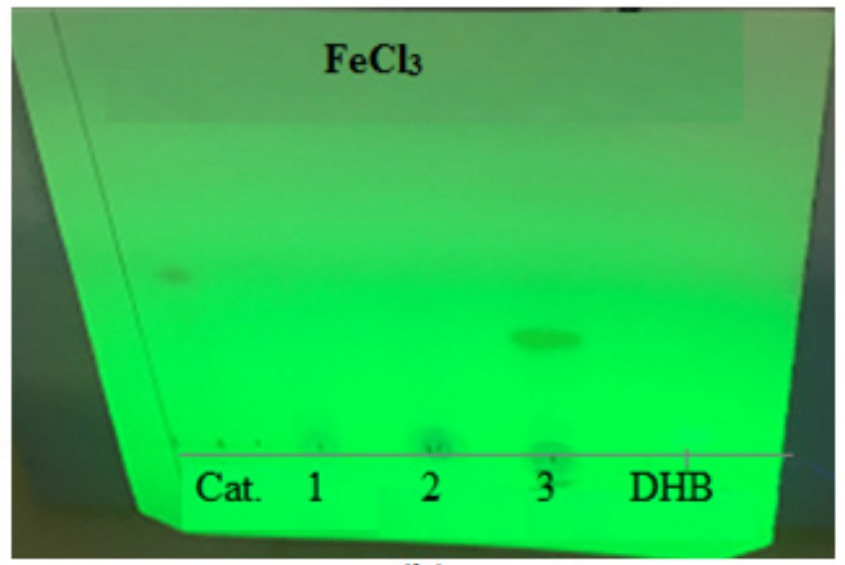

(b)

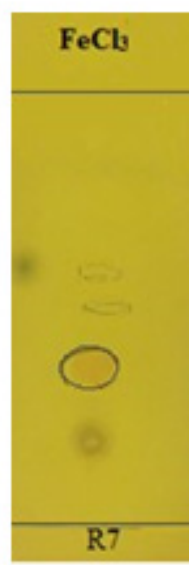

(c)

Figure 3. Detection of siderophore types by TLC with $\mathrm{FeCl}_{3}$ and Gibbs reagents. In (a,b), the left spotted sample (Cat.) was catechol and the right spotted sample (DHB) was 3,4 dihydroxybenzoic acid; main samples were spotted in the middle; 1, 2 and 3 spots indicate control, F8 and R7 actinomycete isolates, respectively. Plate (a) shows the results in Gibbs reagent in which the brown color indicates the presence of phenolic siderophores. Plates (b,c) show the results in $\mathrm{FeCl}_{3}$ reagent, indicating the presence of hyderoxamate siderophore in red color and phenolic compounds such as catechol in blue or greenish colors. 


\subsection{Biochemical Characterization of Selected Actinomycetes Isolates}

All of the selected actinomycete isolates were positive for protease production and osmotic pressure tolerance tests. The R7, $\mathrm{BH} 4-1$ and $\mathrm{BH} 4-3$ isolates produced amylase and the BH4-1 and BH4-3 isolates also produced chitinase. However, none of the isolates produced neither $\mathrm{HCN}$ nor antifungal volatiles (Table 2).

Table 2. Results of biochemical assays performed on four selected actinomycetes isolates.

\begin{tabular}{|c|c|c|c|c|}
\hline \multirow{2}{*}{ Assay } & \multicolumn{4}{|c|}{ Selected Actinomycetes Isolates } \\
\hline & R7 & F8 & BH4-1 & BH4-3 \\
\hline Amylase & + & - & + & + \\
\hline Chitinase & - & - & + & + \\
\hline Protease & $\overline{+}$ & $\overline{+}$ & + & + \\
\hline Growth in EOPM * & + & + & + & + \\
\hline $\mathrm{HCN}^{\dagger}$ Production & - & - & - & - \\
\hline VOCs $\ddagger$ Production & - & - & - & - \\
\hline
\end{tabular}

${ }^{*}$ EOPM: Elevated Osmotic Pressure Medium, ${ }^{\dagger} \mathrm{HCN}$ : Hydrogen Cyanide, ${ }^{\ddagger}$ VOCs: Volatile Organic Compounds.

\subsection{Molecular Identification of the Two Active Isolates}

Amplified PCR products of 16S rDNA for both R7 and F8 actinobacterial isolates ranged from 1400-1500 bp. Blast results of the sequences revealed that both isolates belong to genus Streptomyces. The R7 isolate is closely related to Streptomyces praecox with $99.31 \%$ identity, while the F8 isolate is closely related to S. globisporus with $99.46 \%$ identity. The phylogenetic tree based on 16s rRNA gene sequences of the Streptomyces strains R7 and F8 is presented in Figure 4.

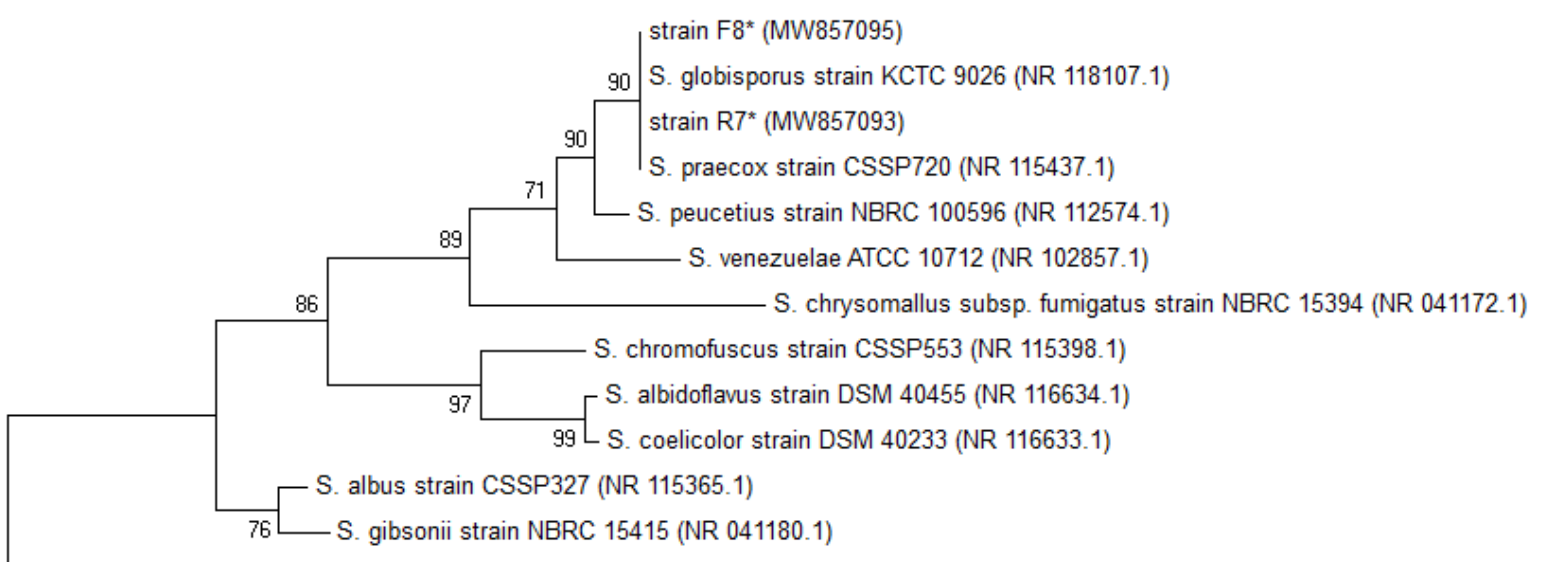

Frankia alni ACN14a (NR 153674.1)

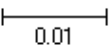

Figure 4. Neighbor joining phylogenetic tree based on 16S rRNA sequences of Streptomyces praecox strain R7 and Streptomyces globisporus strain F8. Frankia alni (Woronin) ACN14a was used as an outgroup. The accession numbers of the sequences are given in parentheses. Bootstrap values are based on 1000 resampling. Bar indicates 0.01 substitutions per nucleotide position. * actinomycetes isolates used in the present study.

\subsection{Root Colonization}

Formation and growth of colonies following the aseptic transfer of cut roots on CGA medium indicated that both Streptomyces strains colonized the tomato seedling roots (Figure 5). Evidently, seed-coated spores germinate, propagate and utilize exudates present at the spermosphere and, hence, acts as roots symbionts. This mutual physiological behavior of the root and symbiont may result in a fully colonized root system. The colonization of roots is a biocontrol behavior of the symbiont actinomycetes species. 


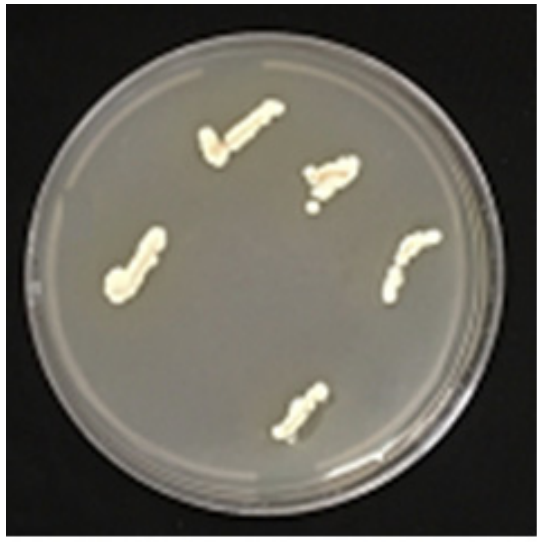

(a)

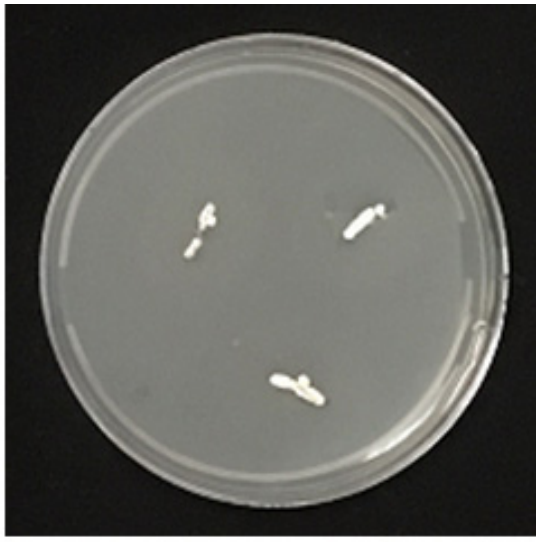

(b)

Figure 5. Result of root colonization of tomato seedling roots by two actinobacteria isolates, R7 and F8. $(\mathbf{a}, \mathbf{b})$ show colonies formed from aseptic transfer of cut roots of R7 and F8 treatment on CGA medium, respectively.

\subsection{Greenhouse Experiments}

Typical symptoms of crown rot and canker caused by R. solani AG4 on tomato cv. Superchief are shown in Figure 6. The results of the biological control of R. solani AG4 by actinomycetes isolates in greenhouse are indicated in Table 3. Among the tested actinomycetes isolates, R7 and F8 isolates promoted noticeable enhancement in seedlings root- length; however, the enhancement in seedling shoot length was greater in R7 than F8 isolates. Furthermore, the R7 isolate significantly increased the seedlings dry weight compared to other isolates $(p \leq 0.05)$. There was no significant difference in enhancement of seedlings dry weight between three other isolates (F8, BH4-1 and BH4-3). Highest disease severity observed in untreated seedlings and maximum disease suppression was noticed in R7 followed by F8 treated seedlings; however, the least amount of suppression was noticed in BH4-1 and BH4-3 treated seedlings as compared to the control (Table 3). Interestingly, R7 and F8 actinomycetes isolates promoted the plant growth and reduced the disease severity (approximately $50 \%$ reduction in disease severity than pathogen treatment), while these isolates did not show antifungal activity in vitro (as indicated above in Figure 1b). We hypothesized that R7 and F8 isolates may induce resistance in tomato plants and therefore these isolates were selected for the gene expression experiments.

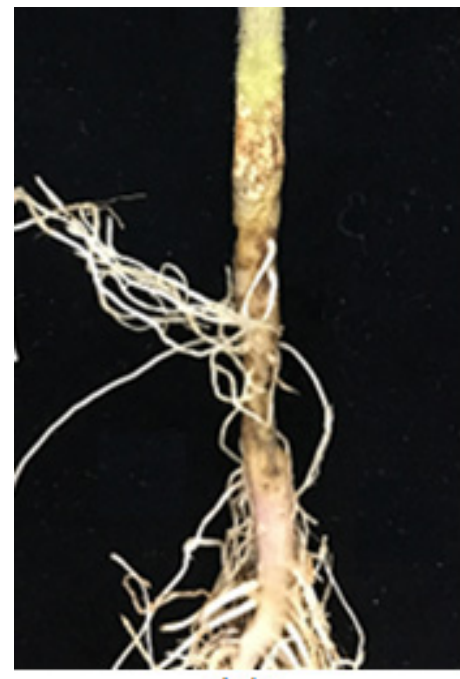

(a)

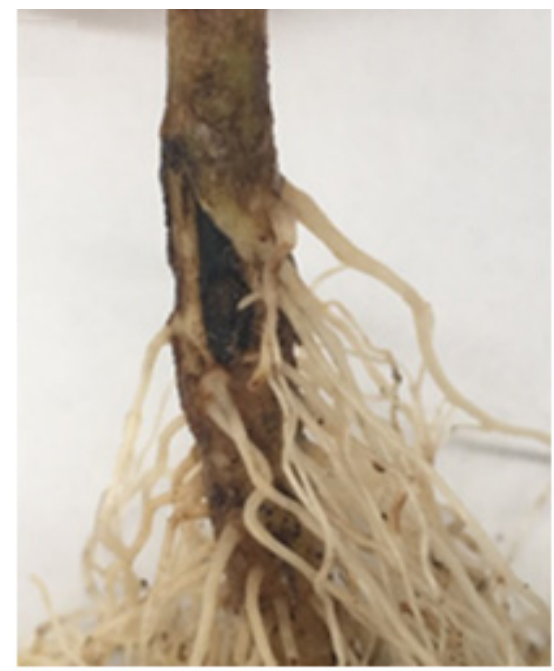

(b)

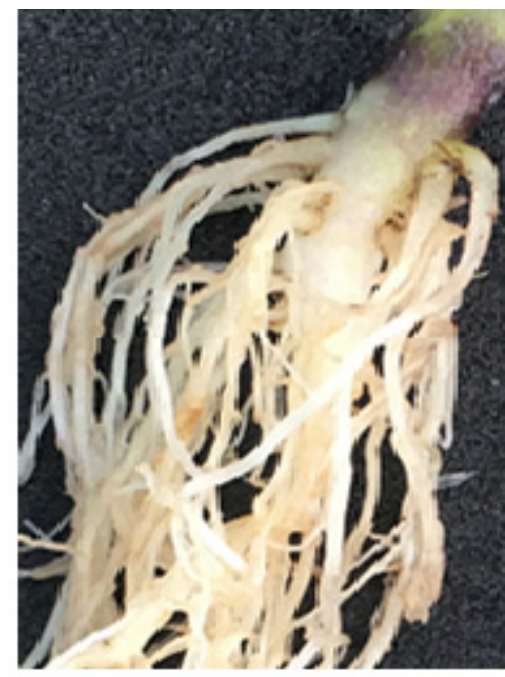

(c)

Figure 6. The symptoms caused by Rhizoctonia solani AG4 on tomato cv. Superchief crown. (a,b) show crown rot and canker, respectively; (c) represents control; uninoculated plant with the pathogen. 
Table 3. Effect of four actinomycetes isolates on tomato seedlings cv. Superchief growth parameters and disease severity. Growth parameters and disease severity were measured simultaneously when seedlings were uprooted and washed; their dry weights were measured after $48 \mathrm{~h}$ incubation at $60^{\circ} \mathrm{C}$.

\begin{tabular}{|c|c|c|c|c|}
\hline Treatment & $\begin{array}{l}\text { Root Length } \\
\text { (cm) }\end{array}$ & Shoot Length (cm) & $\begin{array}{l}\text { Seedlings Dry Weight } \\
(\mathrm{g})\end{array}$ & Disease Severity \\
\hline $\mathrm{R}^{+}$ & $27.75^{a}$ & $44.25^{\mathrm{b}}$ & $3.50^{\mathrm{a}}$ & $1.0^{\mathrm{e}}$ \\
\hline $\mathrm{R} 7+\mathrm{P}$ & $23.25^{b}$ & $45.00^{\mathrm{a}}$ & $3.00^{b}$ & $2.0^{\mathrm{d}}$ \\
\hline $\mathrm{BH} 4-3 \ddagger$ & $22.50^{c}$ & $29.00^{\mathrm{h}}$ & $2.75^{c}$ & $1.0^{\mathrm{e}}$ \\
\hline BH4-3 + P & $9.25^{\mathrm{g}}$ & $21.75^{j}$ & $1.50^{\mathrm{g}}$ & $2.4^{\mathrm{b}}$ \\
\hline $\mathrm{F}^{+}{ }^{+}$ & $27.75^{a}$ & $43.00^{\mathrm{d}}$ & $2.75^{c}$ & $1.0^{\mathrm{e}}$ \\
\hline $\mathrm{F} 8+\mathrm{P}$ & $15.00^{f}$ & $43.50^{c}$ & $2.50^{\mathrm{d}}$ & $2.2^{c}$ \\
\hline $\mathrm{BH} 4-1 \ddagger$ & $21.00^{d}$ & $33.00^{g}$ & $2.75^{c}$ & $1.0^{\mathrm{e}}$ \\
\hline BH4-1 + P & $19.00^{\mathrm{e}}$ & $40.75^{\mathrm{f}}$ & $2.25^{\mathrm{e}}$ & $2.4^{\mathrm{b}}$ \\
\hline Pathogen & $8.00^{h}$ & $28.50^{\mathrm{i}}$ & $2.00^{f}$ & $4.2^{\mathrm{a}}$ \\
\hline Control & $22.50^{\mathrm{c}}$ & $42.50^{\mathrm{e}}$ & $2.50^{\mathrm{d}}$ & $1.0^{\mathrm{e}}$ \\
\hline
\end{tabular}

$+\mathrm{P}$ : shows treatments inoculated with actinomycetes isolate plus pathogen ( $R$. solani AG4). Disease severity values are in accordance with 5 classscales defined by Fery and Dukes (1: without to 5: sever symptom). Values of each column indicated by the same letters have no significant differences according to LSD test $(p \leq 0.05) .{ }^{\dagger}$ : shows actinomycete isolates collected from tomato rhizosphere, ${ }^{\ddagger}$ : shows isolates selected from our laboratory collection.

\subsection{Effect of Streptomyces Globisporus and S. praecox on Defense Related Genes Expression}

In this study, we investigated PAL1 gene expression changes in leaves and roots and $L O X B$ gene expression changes in leaves at different time intervals upon pathogen inoculation in tomato plants that were treated with Streptomyces strains R7 and F8, primarily. Sampling started from the fourth day after the pathogen inoculation along with our observation of the symptoms on the crown of treated plants. Treated plants with Streptomyces strains and pathogen showed smaller lesions on the tomato crown than pathogen-treated plants. This visual comparison indicated strong inhibition of disease development (Figure 7). As indicated in Table 4, mean of lesions length and width on the tomato seedlings crown in plants treated with Streptomyces strains plus pathogen were significantly $(p \leq 0.05)$ smaller than the plants treated with the pathogen alone. Analysis of the LOXB gene expression showed an upregulation of this gene in plants treated with $S$. praecox strain R7 four days post pathogen inoculation ( $4 \mathrm{dpi}$ ) when compared to the negative (untreated with neither pathogen nor Streptomyces strains) and positive control (treated with Streptomyces strains without the pathogen) treatments; however, thereafter the level of gene expression declined gradually. The level of $L O X B$ gene expression increased significantly in the S. globisporus strain F8 treated plants under pathogen impact at 6 dpi compared to negative and positive control 5.3-fold and 3.2-fold, respectively (Figure 8).

Table 4. Mean values of lesion length and width on the crown of the tomato seedlings at the 4th day of pathogen inoculation.

\begin{tabular}{ccc}
\hline Treatment & Mean Length of Lesion $(\mathbf{m m})$ & Mean Width of Lesion $(\mathbf{m m})$ \\
\hline Pathogen $(\mathrm{P})$ & $20.00^{\mathrm{a}}$ & $7.50^{\mathrm{a}}$ \\
F8 + P & $6.50^{\mathrm{b}}$ & $5.00^{\mathrm{a}, \mathrm{b}}$ \\
R7 + P & $7.50^{\mathrm{b}}$ & $3.50^{\mathrm{b}}$ \\
\hline
\end{tabular}

$\overline{\text { Values of each column indicated by the same letters have no significant differences according to LSD test }(p \leq 0.05)}$. 


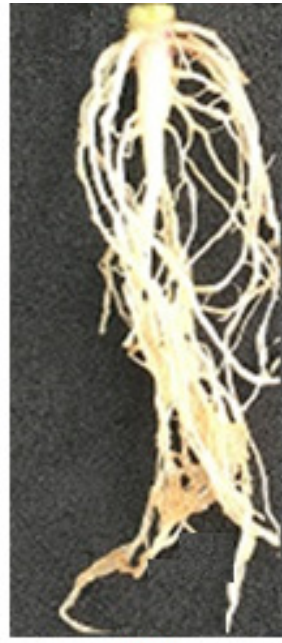

(a)

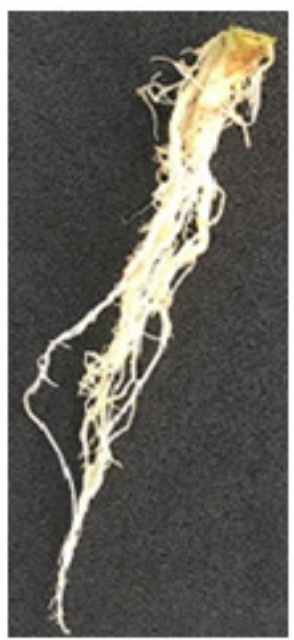

(d)

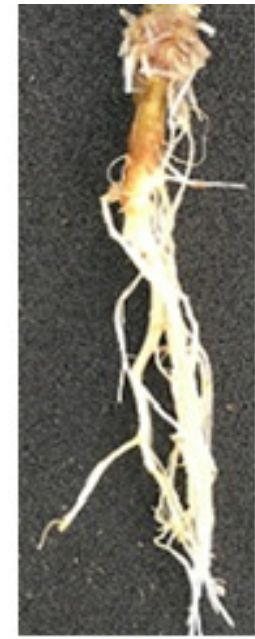

(b)

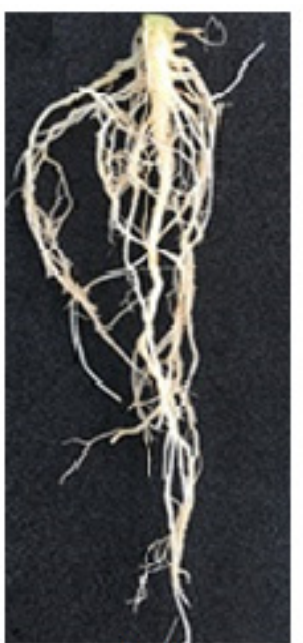

(e)

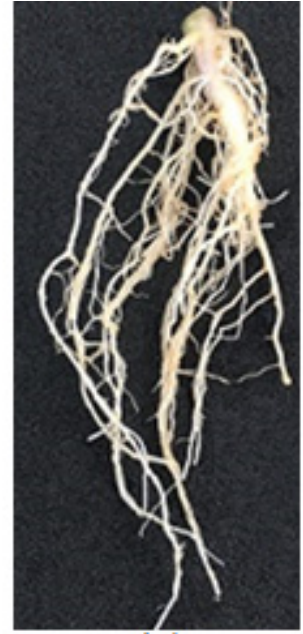

(c)

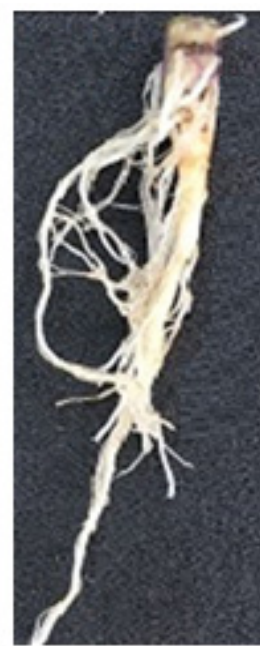

(f)

Figure 7. Comparative results of the biological activity of Streptomyces globisporus strain F8 and S. praecox strain R7 against $R$. solani AG4 on tomato seedlings at the 4 th day after pathogen inoculation. (a): control treatment; (b): plant inoculated with the pathogen alone; $(\mathbf{c}, \mathbf{e})$ : plants inoculated with Streptomyces strains F8 and R7 alone, respectively; $(\mathbf{d}, \mathbf{f})$ : treated seedlings with Streptomyces strains F8 and R7 and pathogen showed smaller lesions than pathogen treatment.

Although a downregulation of PAL1 gene in leaves was noticed in S. globisporous strain F8-treated plants at $4 \mathrm{dpi}$, the expression level of this gene increased consistently and reached the highest expression (5.7-fold higher than untreated unchallenged control) at 6 dpi. There was also a significant difference between levels of PAL1 expression in plants treated with S. globisporous strain F8 before and after the pathogen inoculation at $6 \mathrm{dpi}$. An induction of a stronger defensive reaction was noticeable in pathogen-challenged plants compared to unchallenged controls. In S. praecox strain R7 treated plants, a minor enhancement of PAL1 expression in the leaves was observed at $5 \mathrm{dpi}$ under the pathogen stress compared to the negative control (Figure 9A). Furthermore, the analysis of PAL1 gene expression in roots revealed an enhancement of the gene expression after the pathogen inoculation in plants which were pretreated with S. globisporus strain F8 and S. praecox strain R7 (2.3-folds and 3.3-folds, respectively) at 5 dpi compared to negative control (Figure 9B). 


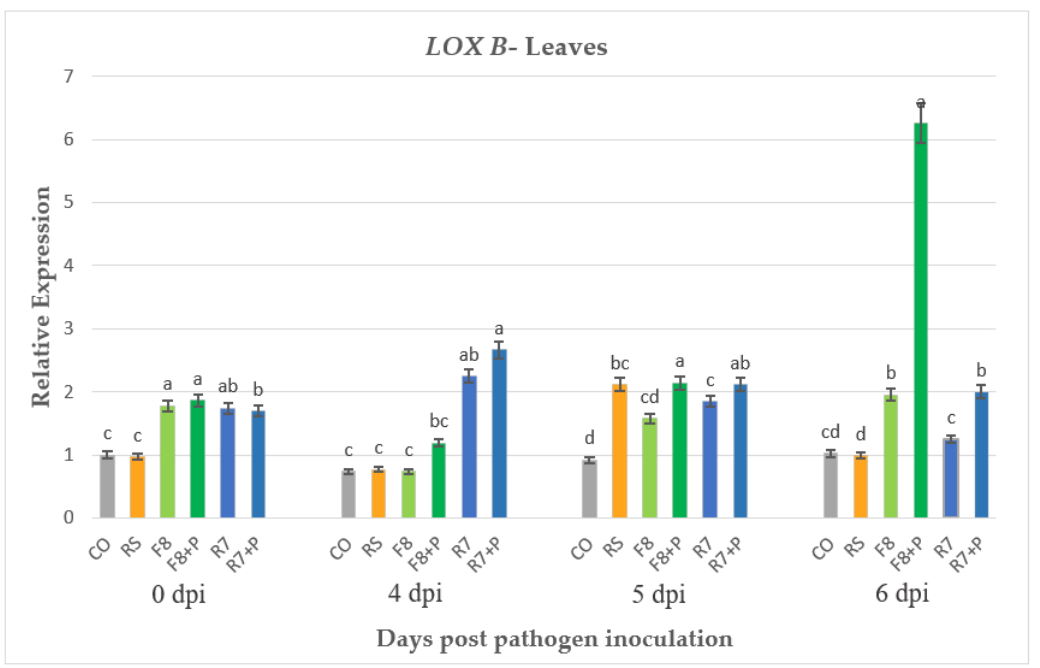

Figure 8. Effects of Streptomyces strains on $L O X B$ gene expression in tomato leaves at different time points in plants inoculated with Rhizoctonia solani AG4. Statistically, values of each column indicated by the same letters $(\mathrm{a}-\mathrm{d})$ have no significant differences according to LSD test $(p \leq 0.05)$. CO: Control treatment without pathogen and Streptomyces; RS: Rhizoctonia solani (pathogen); F8: Streptomyces globisporus strain F8; F8 + P: S. globisporus strain F8 + Pathogen; R7: Streptomyces praecox strain R7 and R7 + P: S. praecox strain R7 + Pathogen. Dpi: day post inoculation with the pathogen; 0 dpi implies the first hours of pathogen infection.
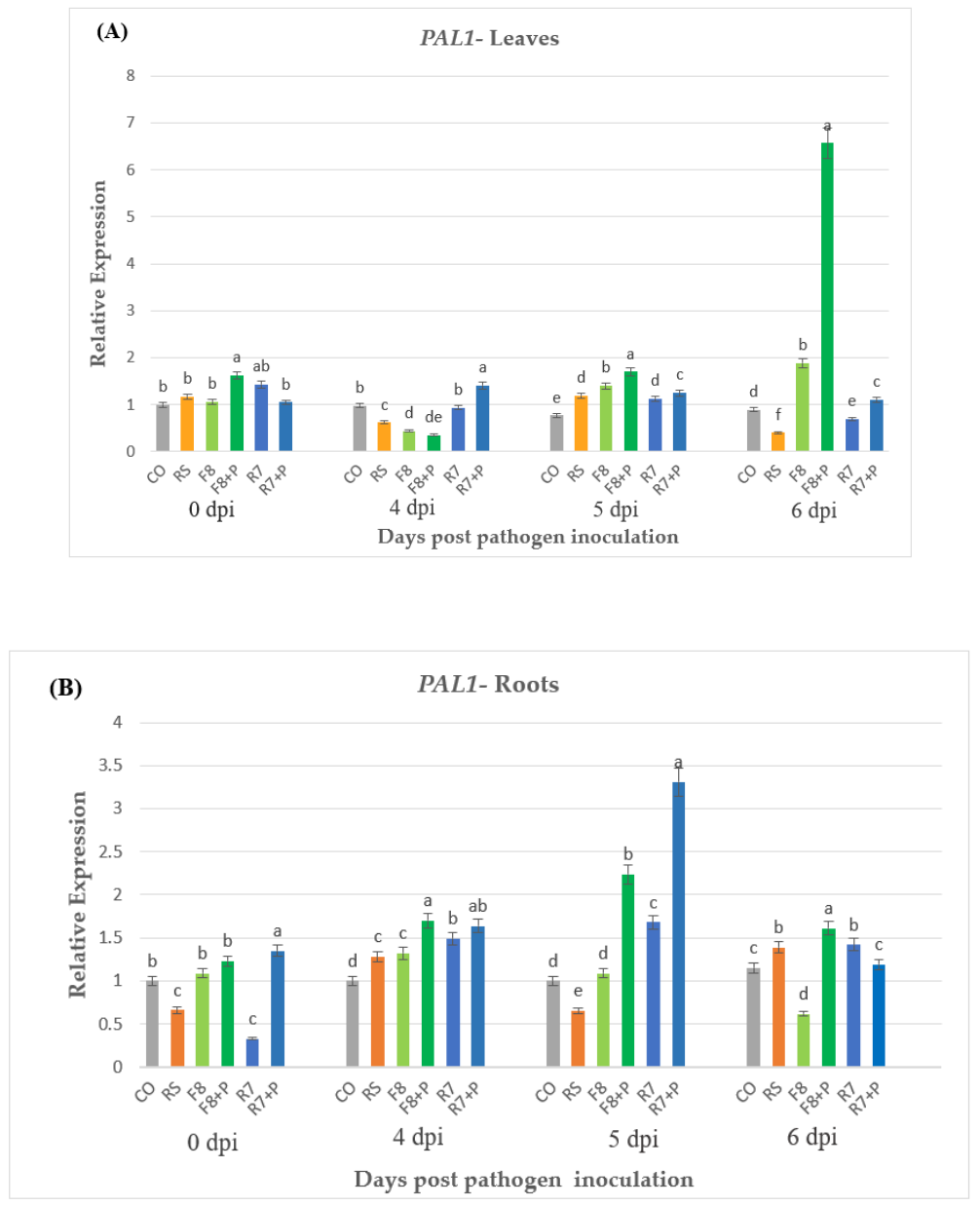

Figure 9. Effects of Streptomyces strains on PAL1 gene expression. (A,B) PAL1 expression changes 
in tomato leaves and roots, respectively, at different time points in plants inoculated with $R$. solani AG4. Statistically, values of each column indicated by the same letters $(a-d)$ have no significant differences according to LSD test $(p \leq 0.05)$. CO: Control treatment without pathogen and Streptomyces; RS: Rhizoctonia solani (pathogen); F8: Streptomyces globisporus strain F8; F8 + P: S. globisporus strain F8 + Pathogen; R7: Streptomyces praecox strain R7 and R7 + P: S. praecox strain R7 + Pathogen. Dpi: day post inoculation with the pathogen; 0 dpi implies the first hours of pathogen infection.

\section{Discussion}

Naturally, plants live with a diversity of microorganisms in the rhizosphere and the phyllosphere. In addition to deleterious interactions where plants deploy their immune system to withstand against pathogens and insects' herbivores, they also establish mutualistic associations with beneficial microbes to improve the plants growth or to assist them in overcoming stress [62]. Thus, beneficial rhizobacteria can enhance plants immunity against pathogens by stimulating the systemic defense pathways including salicylic acid (SA) and jasmonic acid/ethylene (JA/ET) dependent signaling pathways [63,64]. The present study demonstrated that $S$. globisporus and S. praecox are able to enhance the expression of plant defense genes encoding enzymes such as phenylalanine ammonia lyase (PAL) and lipooxygenase (LOX) in tomato seedlings. PAL is one of the most studied enzymes in plant defense responses against biotic and abiotic stresses [65]. PAL is a key enzyme in phenyl propanoid pathway that mediates the biosynthesis of salicylic acid and phenolic compounds such as lignin, suberin and phytoalexins. The phenolic compounds therefore reinforce the plant cell wall preventing the pathogen penetration $[66,67]$. Lipoxygenases are dioxygenases that catalyze the hydroperoxidation of specific unsaturated fatty acids and are involved in the jasmonic acid (JA) biosynthesis in plants [68]. JA and ethylene are signaling molecules that play a basic role in induced systemic resistance (ISR) pathway $[1,69]$. Similar to our results, the treatment of grapevine plant with $S$. anulatus S37 triggered the defense-related genes expression, including genes encoding secondary metabolism of PAL and LOX in response to Botrytis cinerea challenge [70]. Nevertheless, despite the level of gene expression being low during the interaction between S. globisporous strain F8 or S. praecox strain R7 and pathogen in the tomato plant, it may suggest the involvement of JA and SA signaling pathways upon the strain's perception, as reflected by the increased expression of LOX, which is a key element of the oxylipin synthesis, and an induced expression of PAL gene, which was found to be induced by SA. Similar results were reported in grapevine in response to P. fluorescens PTA-CT2 and Burkholderia phytofirmans PsJN [71,72].

Various studies have advocated that most beneficial bacteria primed plants to trigger several cellular defense responses against the pathogen assault [70,73]. Martinez-Hidalgo et al. [22] showed that in the expression of LOXA and Pin $\Pi$, the JA marker genes increased significantly upon Botrytis cinerea challenge in Micromonospora-treated tomato plants. It was indicated that endophytic actinobacteria were able to prime both SAR and JA/ET pathways in Arabidopsis thaliana [74]. Moreover, Kurth et al. [21] showed that not only JA, ET and SA defense pathways but also abscisic acid (ABA) might play a role in Streptomyces mediated priming in Oak plant. Our results showed that the relative expression of some defense-related genes was upregulated by both Streptomyces strains F8 and R7 after R. solani challenge. The results suggest that both bacterial isolates may trigger phenyl propanoid pathway and JA signaling pathway in primed tomato plants; however, we believe that further studies bearing more genes are needed to confirm this suggestion. The maximum enhancement of genes expression has occurred in leaves indicating a systemic resistance. These results are consistent with Patil et al. [19], who reported a higher PAL activity in actinomycetes treated plants after $R$. solani challenge and with report on the induction of defense related enzymes and the accumulation of phenolics and flavonoids in primed tomato plants with actinomycetes under pathogen stress [20]. Our findings are similar to the results of Bacillus cereus AR156 in Arabidopsis, which SA and JA/ET signaling pathways were primed simultaneously [64]. Furthermore, the present results show that Streptomyces strains R7 and F8 were able to activate the plant defense related genes in the absence of pathogen challenge (as also reported by Kurth et al. [21]). The positive effects of acti- 
nomycetes on the biocontrol of $R$. solani on tomatoes were also reported by Goudjal et al. [30] and Singh et al. [20]. The present study demonstrated the role of two Streptomyces strains in promotion of plant growth which are consistent with other studies [14,20,30,75-77]. The present findings are consistent with other previous studies which showed that beneficial bacteria prime plant host for a quicker and a boosted capacity to trigger plant defense responses such as the activation of some defense related genes upon the pathogen challenge [62,70].

The two Streptomyces strains used in this study are strong producers of siderophores, which can trigger plants defense mechanisms. Several studies have demonstrated that siderophores involved in ISR are triggered by plant growth promoting rhizobacteria $[78,79]$. The role of pyochelin siderophore produced by $P$. aeruginosa in the protection of tomatoes against Pythium splendens was demonstrated by Buysens et al. [80]. Furthermore, pseudobactin (Psb374), a siderophore produced by P. fluorescens WCS374, is needed to induce systemic resistance in rice against Magnaporthe oryzae, which is the causal agent of blast disease [81]. Furthermore, purified pseudobactin triggered ISR in Eucalyptus against Ralstonia solanacearum [82]. We believe that further studies are needed to confirm the role of siderophores produced by Streptomyces strains R7 and F8 in triggering the plant defense mechanisms.

Our biochemical characterization showed that both Streptomyces strains R7 and F8 produce protease and are tolerant to high osmotic pressure. However, such criteria indicates that the two active strains may be well activated in saline soils when applied as biocontrol agents. As far as we know, this is the first report from Iran that an induction of resistance by Streptomyces strains in tomatoes against $R$. solani occurs and it is the second report of the usage of actinobacteria as inducer of plant defense against phytopathogens. The present preliminary finding suggests that Streptomyces strains R7 and F8 can promote the plant growth in addition to the protection of the tomato plant against $R$. solani. These Streptomyces strains may be considered as potential candidates for further investigation in the biological control of $R$. solani AG4; the causative agent of tomato crown and root rot disease.

\section{Conclusions}

The results of this research proved that the tomato plants rhizosphere colonizing Streptomyces strains R7 and F8 were able to prime the plants and induce resistance against $R$. solani, which highlight their potential role as candidates in biocontrol strategies for further field trials against the pathogen. In addition to their biocontrol activities, they behaved as plant growth promoting rhizobacteria in tomato plants. To attain their role as determinative biocontrol agents, further in vivo meticulous evaluations are needed to demonstrate their demanded effects in protecting tomato plants against this pathogen in diverse areas of Iran growing tomato.

Author Contributions: M.E.-Z.: Conceptualization, investigation, methodology and writing—original draft preparation. G.H.S.B.: Project administration, supervision, investigation, methodology and writing-review and editing. R.S.R.: Supervision, investigation, methodology and writing-review and editing. M.E.-S.: Supervision and methodology. I.S.: Writing-review and editing. E.A.B.: Writing-review and editing. All authors have read and agreed to the published version of the manuscript.

Funding: This research was supported by the Shahid Bahonar University of Kerman, Kerman, Iran, and partially by Professor Felix Mauch, Department of Biology, Faculty of Science and Medicine, University of Fribourg, Switzerland.

Institutional Review Board Statement: Not applicable.

Informed Consent Statement: Not applicable.

Data Availability Statement: Not applicable.

Acknowledgments: The authors gratefully acknowledge the kind and valuable help of Felix Mauch, Department of Biology, Faculty of Science and Medicine, University of Fribourg, Switzerland, for providing us with qPCR kits and Eliane Abuo-Mansour for her assistance for the characterization of 
siderophores. The spiritual outcome of this research is dedicated to F. Saba and A. Afzalipour, the founders of Universities in Kerman, Iran.

Conflicts of Interest: The authors declare no conflict of interest.

\section{References}

1. Van der Ent, S.; Van Wees, S.C.M.; Pieterse, C.M.J. Jasmonate signaling in plant interactions with resistance-inducing beneficial microbes. Phytochemistry 2009, 70, 1581-1588. [CrossRef] [PubMed]

2. Conrath, U. Molecular aspects of defence priming. Trends Plant Sci. 2011, 16, 524-531. [CrossRef]

3. Conrath, U.; Beckers, G.J.; Flors, V.; García-Agustín, P.; Jakab, G.; Mauch, F.; Newman, M.A.; Pieterse, C.M.; Poinssot, B.; Pozo, M.J.; et al. Priming: Getting ready for battle. Mol. Plant Microbe Interact. 2006, 19, 1062-1071. [CrossRef]

4. $\quad$ Pieterse, C.M.; Leon-Reyes, A.; Van der Ent, S.; Van Wees, S.C. Networking by small-molecule hormones in plant immunity. Nat. Chem. Boil. 2009, 5, 308-316. [CrossRef] [PubMed]

5. Mauch-Mani, B.; Baccelli, I.; Luna Diez, E.; Flors, V. Defense priming: An adaptive Part of induced resistance. Annu. Rev. Plant Biol. 2017, 68, 485-512. [CrossRef] [PubMed]

6. Worrall, D.; Holroyd, G.H.; Moore, J.P.; Glowacz, M.; Croft, P.; Taylor, J.E.; Paul, N.D.; Roberts, M.R. Treating seeds with activators of plant defence generates long-lasting priming of resistance to pests and pathogens. New Phytol. 2012, 193, 770-778. [CrossRef] [PubMed]

7. Luna, E.; Bruce, T.J.; Roberts, M.R.; Flors, V.; Ton, J. Next-generation systemic acquired resistance. Plant Physiol. 2012, 158, 844-853. [CrossRef]

8. Slaughter, A.; Daniel, X.; Flors, V.; Luna, E.; Hohn, B.; Mauch-Mani, B. Descendants of primed arabidopsis plants exhibit resistance to biotic stress. Plant Physiol. 2012, 158, 835. [CrossRef] [PubMed]

9. Van Hulten, M.; Pelser, M.; van Loon, L.C.; Pieterse, C.M.; Ton, J. Costs and benefits of priming for defense in Arabidopsis. Proc. Natl. Acad. Sci. USA 2006, 103, 5602-5607. [CrossRef]

10. Walters, D.R.; Ratsep, J.; Havis, N.D. Controlling crop diseases using induced resistance: Challenges for the future. J. Exp. Bot. 2013, 64, 1263-1280. [CrossRef]

11. Ait Barka, E.; Vatsa, P.; Sanchez, L.; Gaveau-Vaillant, N.; Jacquard, C.; Meier-Kolthoff, J.P.; Klenk, H.P.; Clément, C.; Ouhdouch, Y.; van Wezel, G.P. Taxonomy, physiology, and natural products of actinobacteria. Microbiol. Mol. Biol. Rev. 2016, 80, 1-43. [CrossRef]

12. Bulgarelli, D.; Schlaeppi, K.; Spaepen, S.; van Themaat, E.V.L.; Schulze-Lefert, P. Structure and functions of the bacterial microbiota of plants. Annu. Rev. Plant Biol. 2013, 64, 807-838. [CrossRef]

13. El-Tarabily, K.A.; AlKhajeh, A.S.; Ayyash, M.M.; Alnuaimi, L.H.; Sham, A.; ElBaghdady, K.Z.; Tariq, S.; AbuQamar, S.F. Growth promotion of Salicornia bigelovii by Micromonospora chalcea UAE1, an endophytic 1-aminocyclopropane-1-carboxylic acid deaminase-producing actinobacterial isolate. Front. Microbiol. 2019, 10, 1694. [CrossRef] [PubMed]

14. El-Tarabily, K.A.; ElBaghdady, K.Z.; AlKhajeh, A.S.; Ayyash, M.M.; Aljneibi, R.S.; El-Keblawy, A.; AbuQamar, S.F. Polyamineproducing actinobacteria enhance biomass production and seed yield in Salicornia bigelovii. Biol. Fertil. Soils 2020, 56, 499-519. [CrossRef]

15. Zhang, D.; Lu, Y.; Chen, H.; Wu, C.; Zhang, H.; Chen, L.; Chen, X. Antifungal peptides produced by actinomycetes and their biological activities against plant diseases. J. Antibiot. 2020, 73, 265-282. [CrossRef]

16. Mathew, B.T.; Torky, Y.; Amin, A.; Mourad, A.-H.I.; Ayyash, M.M.; El-Keblawy, A.; Hilal-Alnaqbi, A.; AbuQamar, S.F.; El-Tarabily, K.A. Halotolerant marine rhizosphere-competent actinobacteria promote Salicornia bigelovii growth and seed production using seawater irrigation. Front. Microbiol. 2020, 11, 552. [CrossRef] [PubMed]

17. Saeed, E.E.; Sham, A.; Salmin, Z.; Abdelmowla, Y.; Iratni, R.; El-Tarabily, K.; AbuQamar, S. Streptomyces globosus UAE1, a potential effective biocontrol agent for black scorch disease in date palm plantations. Front. Microbiol. 2017, 8, 1455. [CrossRef] [PubMed]

18. Song, L.; Jiang, N.; Wei, S.; Lan, Z.; Pan, L. Isolation, screening, and identification of actinomycetes with antifungal and enzyme activity assays against Colletotrichum dematium of Sarcandra glabra. Mycobiology 2020, 48, 37-43. [CrossRef]

19. Patil, H.J.; Srivastava, A.K.; Singh, D.P.; Chaudhari, B.L.; Arora, D.K. Actinomycetes mediated biochemical responses in tomato (Solanum lycopersicum) enhances bioprotection against Rhizoctonia solani. Crop Prot. 2011, 30, 1269-1273. [CrossRef]

20. Singh, S.; Gupta, R.; Gaur, R.; Srivastava, A. Antagonistic actinomycetes mediated resistance in Solanum lycopersicon Mill. against Rhizoctonia solani Kühn. Proc. Natl. Acad. Sci. India Sect. B Biol. Sci. 2015, 87, 789-798. [CrossRef]

21. Kurth, F.; Mailänder, S.; Bönn, M.; Feldhahn, L.; Herrmann, S.; Große, I.; Buscot, F.; Schrey, S.D.; Tarkka, M.T. Streptomyces-induced resistance against oak powdery mildew involves host plant responses in defense, photosynthesis, and secondary metabolism pathways. Mol. Plant Microbe Interact. 2014, 27, 891-900. [CrossRef] [PubMed]

22. Martínez-Hidalgo, P.; García, J.M.; Pozo, M.J. Induced systemic resistance against Botrytis cinerea by Micromonospora strains isolated from root nodules. Front. Microbiol. 2015, 6, 922. [CrossRef]

23. Jogaiah, S.; Kurjogi, M.; Govind, S.R.; Huntrike, S.S.; Basappa, V.A.; Tran, L.-S.P. Isolation and evaluation of proteolytic actinomycete isolates as novel inducers of pearl millet downy mildew disease protection. Sci. Rep. 2016, 6, 30789. [CrossRef]

24. Singh, S.P.; Gaur, R. Endophytic Streptomyces spp. underscore induction of defense regulatory genes and confers resistance against Sclerotium rolfsii in chickpea. Biol. Control 2017, 104, 44-56. [CrossRef]

25. Abbasi, S.; Safaie, N.; Sadeghi, A.; Shamsbakhsh, M. Streptomyces strains induce resistance to Fusarium oxysporum f. sp. lycopersici Race 3 in tomato through different molecular mechanisms. Front. Microbiol. 2019, 10, 1505. 
26. Saikia, K.; Bora, L.C. Exploring actinomycetes and endophytes of rice ecosystem for induction of disease resistance against bacterial blight of rice. Eur. J. Plant Pathol. 2021, 159, 67-79. [CrossRef]

27. Solanki, M.K.; Robert, A.S.; Singh, R.K.; Kumar, S.; Pandey, A.K.; Srivastava, A.K.; Arora, D.K. Characterization of mycolytic enzymes of Bacillus strains and their bio-protection role against Rhizoctonia solani in tomato. Curr. Microbiol. 2012, 65, 330-336. [CrossRef]

28. Taheri, P.; Tarighi, S. The role of pathogenesis-related proteins in the tomato-Rhizoctonia solani interaction. J. Bot. 2012, 2012. [CrossRef]

29. Duniway, J. Status of chemical alternatives to methyl bromide for pre-plant fumigation of soil. Phytopathology 2003, 92, 1337-1343. [CrossRef] [PubMed]

30. Goudjal, Y.; Toumatia, O.; Yekkour, A.; Sabaou, N.; Mathieu, F.; Zitouni, A. Biocontrol of Rhizoctonia solani damping-off and promotion of tomato plant growth by endophytic actinomycetes isolated from native plants of Algerian Sahara. Microbiol. Res. 2014, 169, 59-65. [CrossRef]

31. De Curtis, F.; Lima, G.; Vitullo, D.; De Cicco, V. Biocontrol of Rhizoctonia solani and Sclerotium rolfsii on tomato by delivering antagonistic bacteria through a drip irrigation system. Crop Prot. 2010, 29, 663-670. [CrossRef]

32. Berta, G.; Sampo, S.; Gamalero, E.; Massa, N.; Lemanceau, P. Suppression of Rhizoctonia root-rot of tomato by Glomus mossae BEG12 and Pseudomonas fluorescens A6RI is associated with their effect on the pathogen growth and on the root morphogenesis. Eur. J. Plant Pathol. 2005, 111, 279-288. [CrossRef]

33. Montealegre, J.; Valderrama, L.; Sánchez, S.; Herrera, R.; Besoain, X.; Perez, L. Biological control of Rhizoctonia solani in tomatoes with Trichoderma harzianum mutants. Electron. J. Biotechnol. 2010, 13, 717-3458. [CrossRef]

34. Manganiello, G.; Sacco, A.; Ercolano, M.R.; Vinale, F.; Lanzuise, S.; Pascale, A.; Napolitano, M.; Lombardi, N.; Lorito, M.; Woo, S.L. Modulation of tomato response to Rhizoctonia solani by Trichoderma harzianum and its secondary metabolite harzianic acid Front. Microbiol. 2018, 9, 1966. [CrossRef]

35. Ouhaibi-Ben Abdeljalil, N.; Vallance, J.; Gerbore, J.; Yacoub, A.; Daami-Remadi, M.; Rey, P. Combining potential oomycete and bacterial biocontrol agents as a tool to fight tomato Rhizoctonia root rot. Biol. Control. 2021, 155, 104521. [CrossRef]

36. KÜSter, E.; Williams, S.T. Selection of media for isolation of Streptomycetes. Nature 1964, 202, 928-929. [CrossRef]

37. Shahidi Bonjar, G.H.; Fooladi, M.H.; Mahdavi, M.J.; Shahghasi, A. Broadspectrim, a novel antibacterial from Streptomyces sp. Biotechnology 2004, 3, 126-130.

38. Lee, J.Y.; Hwang, B.K. Diversity of antifungal actinomycetes in various vegetative soils of Korea. Can. J. Microbiol. 2002, 48, 407-417. [CrossRef] [PubMed]

39. El-Tarabily, K.; Soliman, M.; Nassar, A.H.; Al-Hassani, D.; Sivasithamparam, K.; McKenna, F.; Hardy, G. Biological control of Sclerotinia minor using a chitinolytic bacterium and actinomycetes. Plant Pathol. 2000, 49, 573-583. [CrossRef]

40. Schwyn, B.; Neilands, J.B. Universal chemical assay for the detection and determination of siderophores. Anal. Biochem. 1987, 160, 47-56. [CrossRef]

41. Hu, Q.-P.; Xu, J.G. A simple double-layered chrome azurol S agar (SD-CASA) plate assay to optimize the production of siderophores by a potential biocontrol agent Bacillus. Afr. J. Microbiol. Res. 2011, 5, 4321-4327.

42. Payne, S.M. Iron acquisition in microbial pathogenesis. Trends Microbiol. 1993, 1, 66-69. [CrossRef]

43. Lee, J.; Postmaster, A.; Soon, H.P.; Keast, D.; Carson, K.C. Siderophore production by actinomycetes isolates from two soil sites in Western Australia. Biometals 2012, 25, 285-296. [CrossRef]

44. Patel, A.K.; Deshattiwar, M.K.; Chaudhari, B.L.; Chincholkar, S.B. Production, purification and chemical characterization of the catecholate siderophore from potent probiotic strains of Bacillus spp. Bioresour. Technol. 2009, 100, 368-373. [CrossRef] [PubMed]

45. Memon, B. Detection of siderophores by thin layer chromatography. J. Chem. Soc. Pak. 2005, 27, 658-661.

46. Mehrotra, S.; Pandey, P.K.; Gaur, R.; Darmwal, N.S. The production of alkaline protease by a Bacillus species isolate. Bioresour. Technol. 1999, 67, 201-203. [CrossRef]

47. Hsu, S.C.; Lockwood, J.L. Powdered chitin agar as a selective medium for enumeration of actinomycetes in water and soil. Appl. Microbiol. 1975, 29, 422-426. [CrossRef] [PubMed]

48. Amoozegar, M.A.; Malekzadeh, F.; Malik, K.A. Production of amylase by newly isolated moderate halophile, Halobacillus sp. strain MA-2. J. Microbiol. Methods 2003, 52, 353-359. [CrossRef]

49. Fernando, W.G.D.; Ramarathnam, R.; Krishnamoorthy, A.S.; Savchuk, S.C. Identification and use of potential bacterial organic antifungal volatiles in biocontrol. Soil Biol. Biochem. 2005, 37, 955-964. [CrossRef]

50. Tresner, H.D.; Hayes, J.A.; Backus, E.J. Differential tolerance of Streptomycetes to sodium chloride as a taxonomic aid. Appl. Microbiol. 1968, 16, 1134-1136. [CrossRef]

51. Alström, S.; Burns, R.G. Cyanide production by rhizobacteria as a possible mechanism of plant growth inhibition. Biol. Fert. Soils 1989, 7, 232-238. [CrossRef]

52. Atashpaz, S.; Khani, S.; Barzegari, A.; Barar, J.; Zununi Vahed, S.; Azarbaijani, R.; Omidi, Y. A robust universal method for extraction of genomic DNA from bacterial species. Mikrobiologiia 2010, 79, 562-566. [CrossRef] [PubMed]

53. Lane, D.J.; Pace, B.; Olsen, G.J.; Stahl, D.A.; Sogin, M.L.; Pace, N.R. Rapid determination of 16S ribosomal RNA sequences for phylogenetic analyses. Proc. Natl. Acad. Sci. USA 1985, 82, 6955-6959. [CrossRef] 
54. Torabi, A.; Shahidi Bonjar, G.H.; Abdolshahi, R.; Pournamdari, M.; Saadoun, I.; Barka, E.A. Biological control of Paecilomyces formosus, the causal agent of dieback and canker diseases of pistachio by two strains of Streptomyces misionensis. Biol. Control 2019, 137, 104029. [CrossRef]

55. Zhang, X.-Y.; Yu, X.-X.; Yu, Z.; Xue, Y.-F.; Qi, L.-P. A simple method based on laboratory inoculum and field inoculum for evaluating potato resistance to black scurf caused by Rhizoctonia solani. Breed. Sci. 2014, 64, 156-163. [CrossRef]

56. Harris, A.R.; Schisler, D.A.; Neate, S.M. Culture of Rhizoctonia solani and binucleate Rhizoctonia spp. on organic substrates for inoculation of seedlings in containers. Soil Biol. Biochem. 1993, 25, 337-341.

57. Fery, R.L.; Dukes, P.D. Southern blight (Sclerotium rolfsii Sacc.) of cowpea: Yield-loss estimates and sources of resistance. Crop Prot. 2002, 21, 403-408. [CrossRef]

58. Livak, K.J.; Schmittgen, T.D. Analysis of relative gene expression data using real-time quantitative PCR and the $2^{-\Delta \Delta C T}$ Method. Methods 2001, 25, 402-408. [CrossRef] [PubMed]

59. Chandrasekaran, M.; Chun, S.C. Expression of PR-protein genes and induction of defense-related enzymes by Bacillus subtilis CBR05 in tomato (Solanum lycopersicum) plants challenged with Erwinia carotovora subsp. carotovora. Biosci. Biotech. Biochem. 2016, 80, 2277-2283. [CrossRef]

60. Song, Y.; Chen, D.; Lu, K.; Sun, Z.; Zeng, R. Enhanced tomato disease resistance primed by arbuscular mycorrhizal fungus. Front. Plant Sci. 2015, 6, 786. [CrossRef]

61. Rotenberg, D.; Thompson, T.S.; German, T.L.; Willis, D.K. Methods for effective real-time RT-PCR analysis of virus-induced gene silencing. J. Virol. Methods 2006, 138, 49-59. [CrossRef]

62. Verhage, A.; van Wees, S.C.M.; Pieterse, C.M.J. Plant immunity: It's the hormones talking, but what do they say? Plant Physiol. 2010, 154, 536-540. [CrossRef] [PubMed]

63. Morcillo, R.J.; Singh, S.K.; He, D.; An, G.; Vílchez, J.I.; Tang, K.; Yuan, F.; Sun, Y.; Shao, C.; Zhang, S.; et al. Rhizobacterium-derived diacetyl modulates plant immunity in a phosphate-dependent manner. Embo J. 2020, 39, e102602. [CrossRef]

64. Niu, D.D.; Liu, H.X.; Jiang, C.H.; Wang, Y.P.; Wang, Q.Y.; Jin, H.L.; Guo, J.H. The plant growth-promoting rhizobacterium Bacillus cereus AR156 induces systemic resistance in Arabidopsis thaliana by simultaneously activating salicylate- and jasmonate/ethylenedependent signaling pathways. Mol. Plant Microbe Interact. 2011, 24, 533-542. [CrossRef] [PubMed]

65. Kim, D.S.; Hwang, B.K. An important role of the pepper phenylalanine ammonia-lyase gene (PAL1) in salicylic acid-dependent signalling of the defence response to microbial pathogens. J. Exp. Bot. 2014, 65, 2295-2306. [CrossRef] [PubMed]

66. Dixon, R.A.; Achnine, L.; Kota, P.; Liu, C.J.; Reddy, M.S.S.; Wang, L. The phenylpropanoid pathway and plant defence-a genomics perspective. Mol. Plant Pathol. 2002, 3, 371-390. [CrossRef]

67. La Camera, S.; Gouzerh, G.; Dhondt, S.; Hoffmann, L.; Fritig, B.; Legrand, M.; Heitz, T. Metabolic reprogramming in plant innate immunity: The contributions of phenylpropanoid and oxylipin pathways. Immunol. Rev. 2004, 198, 267-284. [CrossRef]

68. Feussner, I.; Wasternack, C. The lipoxygenase pathway. Annu. Rev. Plant Biol. 2002, 53, 275-297. [CrossRef] [PubMed]

69. Bannenberg, G.; Martínez, M.; Hamberg, M.; Castresana, C. Diversity of the enzymatic activity in the lipoxygenase gene family of Arabidopsis thaliana. Lipids 2009, 44, 85-95. [CrossRef] [PubMed]

70. Vatsa-Portugal, P.; Aziz, A.; Rondeau, M.; Villaume, S.; Morjani, H.; Clément, C.; Ait Barka, E. How Streptomyces anulatus primes grapevine defenses to cope with gray mold: A study of the early responses of cell suspensions. Front. Plant Sci. 2017, 8, 1043. [CrossRef] [PubMed]

71. Gruau, C.; Trotel-Aziz, P.; Villaume, S.; Rabenoelina, F.; Clément, C.; Baillieul, F.; Aziz, A. Pseudomonas fluorescens PTA-CT2 triggers local and systemic immune response against Botrytis cinerea in grapevine. Mol. Plant Microbe Interact. 2015, 28, 1117-1129. [CrossRef] [PubMed]

72. Miotto-Vilanova, L.; Jacquard, C.; Courteaux, B.; Wortham, L.; Michel, J.; Clément, C.; Barka, E.A.; Sanchez, L. Burkholderia phytofirmans PsJN confers grapevine resistance against Botrytis cinerea via a direct antimicrobial effect combined with a better resource mobilization. Front. Plant Sci. 2016, 7, 1236. [CrossRef] [PubMed]

73. Goellner, K.; Conrath, U. Priming: It's all the world to induced disease resistance. Eur. J. Plant Pathol. 2008, 121, $233-242$. [CrossRef]

74. Conn, V.M.; Walker, A.R.; Franco, C.M. Endophytic actinobacteria induce defense pathways in Arabidopsis thaliana. Mol. Plant Microbe Interact. 2008, 21, 208-218. [CrossRef] [PubMed]

75. Passari, A.K.; Chandra, P.; Zothanpuia; Mishra, V.K.; Leo, V.V.; Gupta, V.K.; Kumar, B.; Singh, B.P. Detection of biosynthetic gene and phytohormone production by endophytic actinobacteria associated with Solanum lycopersicum and their plant-growthpromoting effect. Res. Microbiol. 2016, 167, 692-705. [CrossRef]

76. Goudjal, Y.; Toumatia, O.; Sabaou, N.; Barakate, M.; Mathieu, F.; Zitouni, A. Endophytic actinomycetes from spontaneous plants of Algerian Sahara: Indole-3-acetic acid production and tomato plants growth promoting activity. World J. Microb. Biot. 2013, 29, 1821-1829. [CrossRef]

77. Suárez-Moreno, Z.R.; Vinchira-Villarraga, D.M.; Vergara-Morales, D.I.; Castellanos, L.; Ramos, F.A.; Guarnaccia, C.; Degrassi, G.; Venturi, V.; Moreno-Sarmiento, N. Plant-growth promotion and biocontrol properties of three Streptomyces spp. isolates to control bacterial rice pathogens. Front. Microbiol. 2019, 10, 290. [CrossRef]

78. Höfte, M.; Bakker, P. Competition for iron and induced systemic resistance by siderophores of plant growth promoting rhizobacteria. In Soil Biology, Microbial Siderophores; Varma, A., Chincholkar, S.B., Eds.; Springer: Berlin/Heidelberg, Germany, 2007; pp. 121-133. 
79. Aznar, A.; Dellagi, A. New insights into the role of siderophores as triggers of plant immunity: What can we learn from animals? J. Exp. Bot. 2015, 66, 3001-3010. [CrossRef]

80. Buysens, S.; Heungens, K.; Poppe, J.; Hofte, M. Involvement of pyochelin and pyoverdin in suppression of Pythium-induced damping-off of tomato by Pseudomonas aeruginosa 7NSK2. Appl. Environ. Microbiol. 1996, 62, 865-871. [CrossRef]

81. De Vleesschauwer, D.; Djavaheri, M.; Bakker, P.A.H.M.; Höfte, M. Pseudomonas fluorescens WCS374r-induced systemic resistance in rice against Magnaporthe oryzae is based on pseudobactin-mediated priming for a salicylic acid-repressible multifaceted defense response. Plant Physiol. 2008, 148, 1996-2012. [CrossRef]

82. Ran, L.X.; Loon, L.; Bakker, P. No role for bacterially produced salicylic acid in rhizobacterial induction of systemic resistance in Arabidopsis. Phytopathology 2005, 95, 1349-1355. [CrossRef] [PubMed] 